\title{
Determinants of Attractiveness in Social Stock Exchange
}

\author{
Simone Vasconcelos Ribeiro Galina ${ }^{1}$, Perla Calil Pongeluppe Wadhy Rebehy ${ }^{1}$, Luísa Margarida Cagica \\ Carvalho $^{2} \&$ Maria Teresa Gomes Valente da Costa ${ }^{2}$ \\ ${ }^{1}$ Faculdade de Economia, Administração e Contabilidade, University of São Paulo, Ribeirão Preto, Brazil \\ ${ }^{2}$ Business School, Setúbal Polytechnic Institute, and CEFAGE, University of Evora, Évora, Portugal \\ Correspondence: Perla Calil Pongeluppe Wadhy Rebehy, University of São Paulo, Bandeirantes Avenue 3900, \\ Ribeirão Preto, SP 14024-010, Brazil. Tel: 55-16-3602-3903.E-mail: perla@usp.br, svgalina@usp.br
}

Received: July 30, $2013 \quad$ Accepted: August 18, $2013 \quad$ Online Published: November 18, 2013

doi:10.5539/jms.v3n4p157 URL: http://dx.doi.org/10.5539/jms.v3n4p157

\begin{abstract}
This paper aims to identify an attractiveness pattern of social project that lead to successful funding of projects in social stock exchanges (SSE). This empirical study was based on data published on the SSE sites. Data were obtained during 2012, totalizing 155 projects, from BVSA (Brazil), BVS (Portugal), and SASIX (South Africa). Data analyze were by descriptive statistics (crosstabs) and multiple linear regression.

The results show no linear relationship between attractiveness and the social project characteristics selected for this work. In spite of this, it was possible to identify some common vectors concerning the projects with success in funding. This paper provides two important contributions. First it considers SSE as a model based on transparency which empowers investors to find social value of each project. Second it sheds light on an investment pattern to identify characteristics of social projects that are more prone to obtain financial resource.
\end{abstract}

Keywords: financial resource, social entrepreneurship, social innovation, social value, BVS, BVSA, SASIX

\section{Introduction}

Social organisations play an important role by detecting and exploring social opportunities. Frequently they are the solution to social problems where market and government fail. Additionally, social entrepreneurs have a key role in contemporary societies identifying and solving social problems where others just see barriers, since they evaluate opportunities, disseminate new approaches, and propose sustainable solutions that contribute to create social value.

Social entrepreneurship is an emerging theme for research, since relatively little scholarly output has appeared in mainstream management and entrepreneurship journals (Short, Moss, \& Lumpkin, 2009). As a developing area of study, some issues are lacking. Measuring social value, social performance and impact of social projects is one of the greatest challenges for practitioners and researchers in social entrepreneurship (Certo \& Miller, 2008; Mair \& Marti, 2006).

The inexistence of appropriated metrics for projects returns directly impact on the difficulties for mobilizing financial resources by social entrepreneurs (Certo \& Miller, 2008). Financial assessing is one of the topics pointed by Haugh (2005) in the social entrepreneurship research agenda, including "the research on motivations and investment choice process of social investors, either institutionally or as social business angels" (Haugh, 2005, p. 7).

Thus, intending to contribute to this literature, the present paper presents an analysis of the characteristics of social projects included in the Social Stock Exchange (SSE). This is an innovative funding acquisition structure, and we have studied three pioneer SSE in the world: Brazilian BVSA, Portuguese BVS and South African SASIX. SSE replicates the atmosphere of a stock exchange, whose role is to approach civil society organisations with social investors who can support them by purchasing their social shares. This is an innovative approach to attract financial resources in order to solve social problems.

Through the promotion of social investment, the SSE proposes an innovative financial model based not only on philanthropy or on charity, but on transparency which enables a better decision from investors based on the social profit of each project. Although SSE was originally proposed - and is still oriented - to projects from non-governmental organization (NGO), this may be an innovative fund-raising model for any kind of social 
project. Thus shedding light on the decision rules that investors use at SSEs may contribute to identify characteristics of social projects that are more prone to obtain financial resource. The NGOs address different range of activities, and they act at different levels, some of them operate at an intergovernmental level, national level, grassroots level and across a range of distinct levels (Unerman \& O'Dwyer, 2010).

Considering the issues above, this paper aims to answer the following question: Which factors lead to successful funding of projects in social stock exchanges? Thus, the main goal of this paper is to identify an attractiveness pattern of social project in terms of funding, public target, location (capital or countryside), geographic scope, scope of activities, size, and three dimensions of sustainability: social, environmental (both measured through millennium development goals-MDG) and economic. The specific objectives are the following: (i) to describe the characteristics of SSE projects of three countries according to their respective differences and similarities, and (ii) to compare the characteristics to the financial attractiveness of the project in order to identify factors that were present in highly attractive projects.

This empirical study was based on documental research of data published on the SSE sites. Data were obtained during 2012, totalizing 155 projects, from BVSA (Brazil), BVS (Portugal), and SASIX (South Africa). Data analyze were by descriptive statistics (crosstabs) and multiple linear regression.

This research firstly presents a literature review about social entrepreneurship, social innovation, and social entrepreneur, considering different approaches and perspectives, before presenting the results.

\subsection{Value Creation, Social Innovation and Entrepreneurship}

The definition of social entrepreneurship is not consensual and is reflected in the variety of definitions in the literature (Seelos \& Mair, 2005). Social entrepreneurship could be defined as "an innovative, social value-creating activity that can occur within or across the non-profit, business or government sector" (Austin, Stevenson, \& Wei-Skillern, 2006, p. 2).

Costa and Carvalho (2012), tried to group the various definitions of social entrepreneurship by having found three major groups:

1 - First group: social entrepreneurship refers to the initiatives of social organisations in the search for alternative financing strategies or as a way of creating social value through management practices (Austin et al., 2006; Boschee, 1998; Dees, 1998).

2 - Second group: social entrepreneurship considers the independent initiatives of social entrepreneurs who seek to alleviate a social problem and catalyse social transformation (Alvord, Brown, \& Letts, 2002, 2004).

3 - Third group: social entrepreneurship includes a set of practices of social responsibility of companies involved in partnerships with other sectors (Sagawa \& Segal, 2000; Waddock, 1988).

Additionally, some authors argue that social entrepreneurship involves pattern-breaking change (Light, 2006, 2008) e.g. innovation. Social innovation is about "innovative activities and services that are motivated by the goal of meeting a social need and that are predominantly developed and diffused through organizations whose primary purposes are social" (Mulgan, Tucker, Sli, \& Sanders, 2007, p. 8).

According to Phills, Deiglmeier and Miller (2008) social innovation is a novel answer to a social problem that is more effective, efficient, and sustainable. This kind of answer allows the creation of value to society. The same authors define social value as the creation of benefits or reduction of costs for society that enables the solution for social needs. Also Leadbeater (2007, p. 2) refers that:

All innovation involves the application of new ideas - or the re-application of old ideas in new ways - to devise better solutions to our needs. Innovation is invariably a cumulative, collaborative activity in which ideas are shared, tested, refined, developed, and applied. Social innovation applies this thinking to social issues: education and health, issues of inequality and inclusion.

One important aspect of social innovation is its characteristic of being diffused through organisations whose primary purposes are social (Mulgan et al., 2007). Phills et al. (2008) highlight that advanced results from social innovations should be incorporated into the whole society rather than being considered private properties.

Besides social innovation, another aspect focus by researches is that social entrepreneurship involves new social value creation (Austin et al., 2006). According to Dees (1998) there are distinctions between social value creation and commercial value creation. Traditional entrepreneurship, economic rents growth depends on ability of innovator to explore opportunity gaps and its main goal is maximize profitability. In opposition, another perspective proposed by Calás, Smircich and Bourne (2009) frame entrepreneurship in the context of social change. Value creation of social projects is created from following the organization's mission as social 
entrepreneurs (individuals, groups, networks, organizations, or private-public partnerships) considering new ways to solve social needs issues (Light, 2006, 2008).

Social Stock Exchange can be refereed as an example of social innovation. In this case, the replication is made based on the atmosphere of a stock exchange. This environment creates a network that facilitate the relationship between Civil Society Organizations that creates social value in the area of Education and Entrepreneurship, and social investors (donors) that support these organizations by purchasing their social actions (Costa \& Carvalho, 2012).

\subsection{Sources of Opportunities and Resource Raising}

Recognition and exploitation of opportunities are key issues in social entrepreneurship (Austin et al., 2006; Mair \& Marti, 2006). Considering that social entrepreneurship has particular features, distinguished from the commercial opportunities (Austin et al., 2006; Dorado, 2006; Mair, 2006; Robinson, 2006), several authors point out the uniqueness of social opportunities in comparison to commercial ones, namely:

- Social entrepreneurship opportunities are focused on social problems and they involve attempts to create social value (Dees, 2001; Thompson, 2002). Social value creation is concerned with the resolution of social issues, such as generating income for economically disadvantaged people or delivering medical supplies to poverty-stricken areas of the globe. This requires innovation just as the commercial sector does by creating economic value (Dees, 2001, 2007). Opportunities to create social value emerge through philanthropic activities and social activism (e.g. fair trade importing) as well as through notions of self-help showing that engendering systems for enabling people to help themselves is similar to the microfinance movement (Hockerts, 2006).

- Social entrepreneurship opportunities can be distinguished depending on the context in which these opportunities emerge, including their recognition and exploitation.

In fact, social (people) and environmental (planet) problems have presented as opportunities for social entrepreneurs (Neck, Brush, \& Allen, 2009). Identification and exploitation of opportunities provide solutions for social problems, such as lack of healthcare and education, poverty, and starvation, as well as technologies and innovations to solve environmental problems, such as energy, water, and global warming.

Entrepreneurial projects require resources, and like the traditional entrepreneurs, social entrepreneurs must find a range of tools and strategies to attract resources. Entrepreneurship literature (Aldrich \& Zimmer, 1986; Birley, 1985; Johannisson, 2000) provides several studies on entrepreneurial networks and their fundamental role in providing access to knowledge, information, and resources. Some of those studies highlight strategies followed by entrepreneurs in order to attract resources, such as use of networks and social resourcing, financial bootstrapping, and strategies of achievement (Domenico, Haugh, \& Tracey, 2010).

Some studies in the field of social entrepreneurship exemplify cases of resources acquisition through networks, showing that some are tangible (the case of capital and physical assets) and others are relational. It is possible to note that entrepreneurs frequently use personal networks, such as kinship ties and family mentors, to obtain support, skills, and experience, thereby facilitating market penetration (Domenico et al., 2010).

Although this sector has this source of funding, there are multilateral organizations that offer resources elsewhere. They provided development aid to developing nations (termed Official Development Assistance) amounting to US\$121.5 billion (OECD 2009), and of this total US\$ 2.5 as being provided as direct governmental funding of NGOs.

Nancy and Yontcheva (2006) pointed some indicators used to explain country allocations of aid: per capita income levels (Dudley and Montmarquette as cited by Nancy and Yontcheva, 2006), life expectancy, literacy rates, caloric intake (McKinley \& Little as cited by Nancy and Yontcheva, 2006) or combinations of various such indicators aimed at establishing summary measures of the quality of life in recipient countries. They did study cross- country and add other variables like: militarization of the countries, poverty, population, imports from EU, EU official aid. Their results showed that financial aid was driven by poverty with 0,931 correlation and other variables were not significant.

After the credit crunch, Unerman and O'Dwyer (2010) pointed two important aspects to assure NGOs sustainability: (i) maintain their commitment to achieve the MDG (Millennium Development Goal), for example spend 0.7 per cent of gross national income as part of a package of measures aimed at alleviating poverty; (ii) global warming disproportionately has negative impacts on the poorest in the world.

Despite the difficulties in raising financial resources for social projects, one can think of mechanisms used by for-profit entrepreneurships, such as venture capital, private equity, credit market (financing lines), capital 
market (with no finance intermediates). In all options, the investors require a financial return on the invested capital, although the capital market rationale was the starting point because it is a resource-raising process with no finance intermediates. In the capital market, resources come from spenders and savers by means of issuing commercial papers, such as bonds, stocks, and others. On the other hand, social stock exchanges use this rationale to capture resources from civil organizations and social investors who seek social rather than financial return.

Cruz (2000) pointed out the funding sources of NGOs and their implications: (i) individuals, whose resources can be applied freely, offer more involvement and can be volunteers, legitimizing agents of the organization, and can be sporadic or monthly membership; (ii) business: partnerships add visibility to the cause; higher values; possibility offering specialized volunteers; (iii) Foundations and International Agencies: give credibility to the organization, the values usually come at once; identification with NGOs, can offer assistance and training; (iv) Governmental Public Resources: large sums for long periods; legitimation and tax exemptions; (v) Income Generation Projects: independence and better planning, generation employment, open space for innovation and creativity; (vi) Events: marketing and distribution, approach with the community; (vii) Churches: disclosure project, identification with the cause, support for long periods.

\section{Method}

Each method of procedure suggests the use of instruments suitable to operationalize the objectives. This paper used documental and field research to collect information. Data were collected from the following social stock exchanges during the year of 2012:

- Bolsa de Valores Sociais [BVS] from Portugal http://www.bvs.org.pt/view/viewProjetos.php.

- Bolsa de Valores Sociais Ambientais [BVSA] from Brasil http://www.bvsa.org.br/portfolio-de-projetos; and

- SASIX from South Africa http://www.sasix.co.za/projects/index/all/

Data from all the above-mentioned projects were obtained during 2012, totalising 155 projects, with 66 coming from BVSA (Brazil), 30 from BVS (Portugal), and 59 from SASIX (South Africa).

Table 1. Goals and analysis techniques

\begin{tabular}{ll}
\hline Goals & Analysis techniques \\
\hline $\begin{array}{l}\text { Main goal: to identify a project attractiveness pattern in terms of } \\
\text { funding, public target, location (capital or countryside), geographic }\end{array}$ & 1 ) Linear regression \\
scope, scope of activities, size, and three dimensions of & \\
$\begin{array}{l}\text { sustainability: social, environmental and economic. } \\
\text { Specific goal: (i) to describe the characteristics of the social stock }\end{array}$ & 2) $\quad$ Crosstabs of each country \\
exchange projects of three countries with their respective similarities & \\
and differences. & $\begin{array}{l}\text { 3) Crosstabs of each status (successful or unaccomplished): to } \\
\text { Specific goal: (ii) to compare the initial characteristics to the }\end{array}$ \\
$\begin{array}{l}\text { financial attractiveness of the project in order to identify factors that initial characteristics to the financial attractiveness of the } \\
\text { projects in order to identify factors that were present in projects with } \\
\text { high rates of attractiveness. }\end{array}$ & $\begin{array}{l}\text { 4) Deductive Method to discriminate two groups of project } \\
\text { attractiveness (success and unaccomplished) }\end{array}$ \\
\hline
\end{tabular}

The descriptive analyses were made trough crosstabs in two moments: first to characterize the projects per country (Brazil, Portugal and South Africa) and after to distinguish the attractiveness (unaccomplished and successful). And linear regression was performed with the dependent variable being the financial attractiveness, measured as the proportion between captured value and budgeted value (goal).

In order to reach the goals (Table 1), we used the same independent variables as following: public target, size of the projects, scope of activity, location, geographic scope, and social, economic and environmental sustainability (detailed presented in Table 2). 
Table 2. Description of independent variables

\begin{tabular}{|c|c|c|}
\hline i. & $\begin{array}{l}\text { Values of the projects: these values demonstrate } \\
\text { the size of the project* }\end{array}$ & $\begin{array}{l}\text { - Micro: } 0 \text { to } 10.000 \text { Euros } \\
\text { - Small: } 10.001 \text { to } 30.000 \text { Euros } \\
\text { - Medium: } 30.001 \text { to } 50.000 \text { Euros } \\
\text { - Large: } 50.001 \text { to } 100.000 \text { Euros } \\
\text { - X-Large: Above } 100.001 \text { Euros }\end{array}$ \\
\hline ii. & $\begin{array}{l}\text { Community being attended: which target public } \\
\text { is attended }\end{array}$ & $\begin{array}{l}\text { - Children } \\
\text { - Youth } \\
\text { - Elderly } \\
\text { - Indigenous people } \\
\text { - Traditional populations } \\
\text { - GLBTT } \\
\text { - Women } \\
\text { - Handicapped people } \\
\text { - Afro-descendent people }\end{array}$ \\
\hline iii. & $\begin{array}{l}\text { Scope of activity: to identify whether the project } \\
\text { to be funded aims at }\end{array}$ & $\begin{array}{l}\text { - Education (special, citizenship, sustainability) } \\
\text { - Social entrepreneurship } \\
\text { - Social-economic development }\end{array}$ \\
\hline iv. & Location & $\begin{array}{l}\text { - Capital of the states } \\
\text { - Countryside }\end{array}$ \\
\hline v. & $\begin{array}{l}\text { Geographic scope: to identify whether the } \\
\text { project's approach is }\end{array}$ & $\begin{array}{l}\text { - } \text { regional } \\
\text { - national }\end{array}$ \\
\hline vi. & $\begin{array}{l}\text { Social and environmental sustainability } \\
\text { (measured through MDG) }\end{array}$ & $\begin{array}{l}\text { - without MDG associated } \\
\text { - } \text { poverty eradication } \\
\text { - elementary school for all } \\
\text { - gender equality } \\
\text { - decreased infantile mortality } \\
\text { - improved healthcare for pregnant women } \\
\text { - fight against HIV, malaria and other diseases } \\
\text { - quality of life and respect to environment } \\
\text { - all working for the development }\end{array}$ \\
\hline vii. & Economic Sustainability & $\begin{array}{l}\text { - with economic sustainability } \\
\text { - } \text { without economic sustainability }\end{array}$ \\
\hline
\end{tabular}

*in the regression this variable was used in absolute value.

\section{Results}

The Brazilian stock exchange (BMF \& Bovespa), created in 2003, is the first initiative of SSE, called Bolsa de Valores Sociais Ambientais - BVSA. This organisation has been recognized as being a novel model by UNESCO and recommended by the United Nations for other stock exchanges worldwide via Global Compact, an initiative for encouraging private sector, United Nation's agencies, and social players to contribute for the advance of the corporate social responsibility so that a global economy can be built in a sustainable and inclusive way. (BM \& FBovespa, 2012).

The UN's Global Compact has two objectives:

The first objective is to encourage the alignment of policies and entrepreneurial practices to the principles of human rights, labour rights, environment protection, and fight against corruption. The second objective is to catalyse actions that support the UN's broader goals, including the Millennium Development Objectives (MDOs). (Bolsa de Valores Socioambientais [BVSA], 2012).

Two other social stock exchanges have followed the Brazil's BVSA model: the Portugal's Social Stock Exchange (BVS) and the South African Social Investment Exchange (SASIX). According to Phills et al. (2008), this illustrates a successful process of social innovation as the BVSA innovative model not only went beyond the institution itself, but also extrapolated the borders of the country.

The BVS was the first one in the world to follow the model adopted by the Brazilian stock exchange, being created in 2009 and keeping the same management practices, whereas the SASIX has evolved in terms of management model by incorporating similar tools into those by traditional stock markets.

The SASIX gives priority to projects with measurable social impact and assesses donation as a social investment not because there is no financial return, but by the fact that they make social changes that can be measured. 
SASIX applies the same sort of due diligence consideration to projects as would be applied to purely financial investments, including assessing need and evaluating depth, breadth, permanence, strengths and risks. In this way, the stock exchange classifies projects regarding risk and rating. On the one hand, concept, design, capability, control, sustainability and external factors were considered, on the other hand, purpose, strategy, resource, governance, sustainability and performance were evaluated.

The values of the projects from the three countries were converted into Euros and then ranked according to their level of financial attractiveness as follows: high (above $70 \%$ of the budgeted value), medium ( $30 \%$ to $70 \%$ of the budgeted value), and low (below $29 \%$ of the budgeted value) as shown in Table 3.

Table 3. Levels of attractiveness of the social projects per country

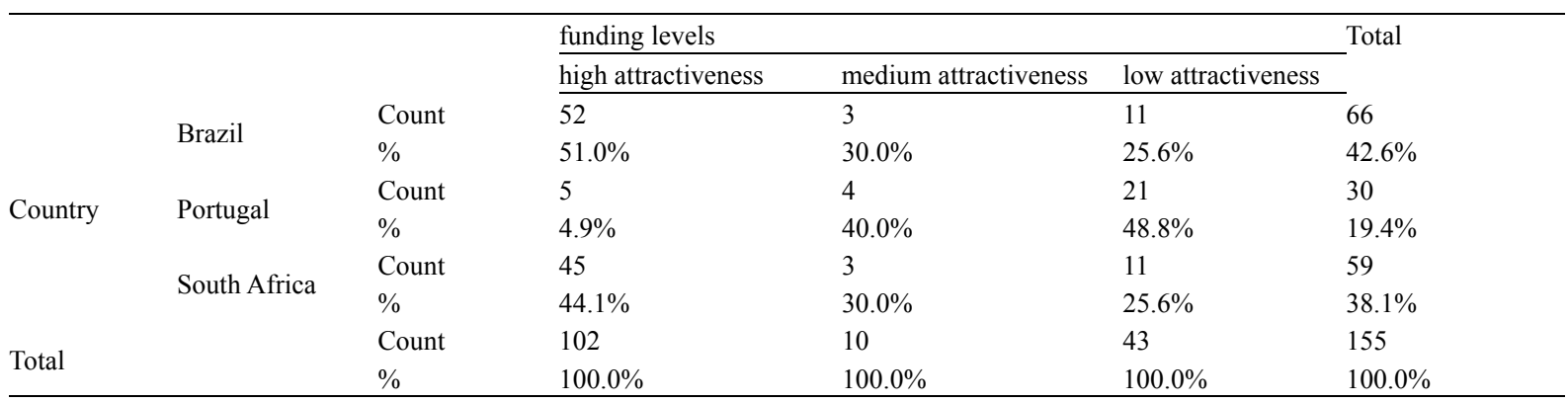

In order to understand the reasons of this attractiveness on these countries, some features of the projects were studied in terms of funding, public target, location (capital/countryside), geographic scope, scope of activities, size, and three dimensions of sustainability.

\subsection{Characterisation of the Projects per Country}

\subsubsection{Public Target}

By assessing the community attended by the total of projects (Table 4), we can see that there is a uniform distribution among children (25.8\%), traditional population (24.5\%) and youth (20.6\%). Handicapped people are also significantly represented in fourth place, with $17.4 \%$.

There are also differences between the projects of each country, mainly between Portugal and Brazil. For instance, the Brazilian projects are more concerned with youth $(39 \%)$ and children $(21 \%)$, whereas the Portuguese projects are more involved with traditional (33\%) and handicapped (27) populations, and the South African projects, with children (37\%) and traditional (27\%) and handicapped (24\%) populations.

Table 4. Target public per country

\begin{tabular}{|c|c|c|c|c|c|c|}
\hline & & & country & & & Total \\
\hline & & & $\underline{\text { Brazil }}$ & Portugal & South Africa & \\
\hline & ohildron & Count & 14 & 4 & 22 & 40 \\
\hline & cniluren & $\%$ & $21.2 \%$ & $13.3 \%$ & $37.3 \%$ & $25.8 \%$ \\
\hline & & Count & 26 & 2 & 4 & 32 \\
\hline & youth & $\%$ & $39.4 \%$ & $6.7 \%$ & $6.8 \%$ & $20.6 \%$ \\
\hline & & Count & 2 & 2 & 0 & 4 \\
\hline & Elderly & $\%$ & $3.0 \%$ & $6.7 \%$ & $0.0 \%$ & $2.6 \%$ \\
\hline & indiganous & Count & 3 & 0 & 0 & 3 \\
\hline Target & indigenous & $\%$ & $4.5 \%$ & $0.0 \%$ & $0.0 \%$ & $1.9 \%$ \\
\hline Public & & Count & 12 & 10 & 16 & 38 \\
\hline & traditional & $\%$ & $18.2 \%$ & $33.3 \%$ & $27.1 \%$ & $24.5 \%$ \\
\hline & & Count & 2 & 3 & 3 & 8 \\
\hline & women & $\%$ & $3.0 \%$ & $10.0 \%$ & $5.1 \%$ & $5.2 \%$ \\
\hline & & Count & 5 & 8 & 14 & 27 \\
\hline & disabilities & $\%$ & $7.6 \%$ & $26.7 \%$ & $23.7 \%$ & $17.4 \%$ \\
\hline & & Count & 2 & 1 & 0 & 3 \\
\hline & negroes & $\%$ & $3.0 \%$ & $3.3 \%$ & $0.0 \%$ & $1.9 \%$ \\
\hline Total & & Count & 66 & 30 & 59 & 155 \\
\hline Iotal & & $\%$ & $100.0 \%$ & $100.0 \%$ & $100.0 \%$ & $100.0 \%$ \\
\hline
\end{tabular}




\subsubsection{Location}

In terms of location of the seat of the organization proposing the project (Table 5), two sites were considered: i) capital of the states of each country or (ii) countryside. Overall, the projects are relatively distributed in a similar way between these both categories, with a slight superiority in the projects out of the capitals (51.6\%). Portugal is an exception, since $63.3 \%$ of the BVS projects are located in the capital.

Table 5. Location of the project per country

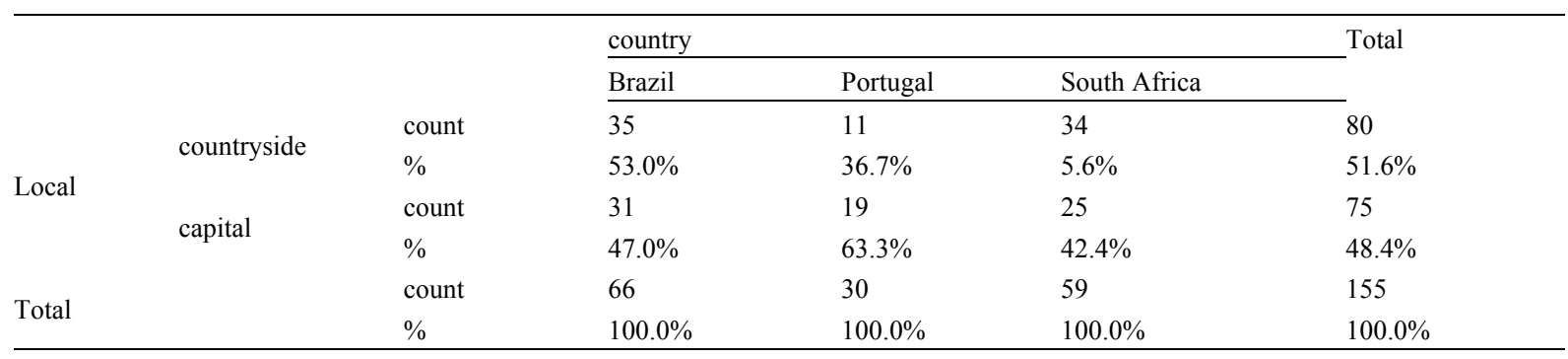

\subsubsection{Geographic Scope}

Although the projects are located in a given city at the moment of their implementation, their reach may have a regional, national or even international scope. Table 6 shows that $84.5 \%$ of the projects have a regional reach, assisting the city or even the district in which they are seated. This might corroborate the inexistence of a national public policy to meet the third sector needs, which stimulates local initiatives to meet the public specific gaps. It was observed that this characteristic is not different between the countries.

Table 6. Geographic scope per country

\begin{tabular}{|c|c|c|c|c|c|c|}
\hline \multirow{5}{*}{ geographic scope } & \multirow{4}{*}{ regional } & \multirow{4}{*}{$\begin{array}{l}\text { count } \\
\%\end{array}$} & \multicolumn{3}{|l|}{ country } & \multirow[t]{2}{*}{ Total } \\
\hline & & & Brazil & Portugal & South Africa & \\
\hline & & & 54 & 24 & 53 & 131 \\
\hline & & & $81.8 \%$ & $80.0 \%$ & $89.8 \%$ & $84.5 \%$ \\
\hline & notionol & count & 12 & 6 & 6 & 24 \\
\hline & Irational & $\%$ & $18.2 \%$ & $20.0 \%$ & $10.2 \%$ & $15.5 \%$ \\
\hline \multirow{2}{*}{ Total } & & count & 66 & 30 & 59 & 155 \\
\hline & & $\%$ & $100.0 \%$ & $100.0 \%$ & $100.0 \%$ & $100.0 \%$ \\
\hline
\end{tabular}

\subsubsection{Scope of Activities}

With regard to the scope of activities of the projects (Table 7), the majority is formed by social entrepreneurships $(34.2 \%)$, but this indicator is increased by the South African social projects, of which $52 \%$ are of this nature. Brazil and Portugal have, respectively, the highest number of projects aimed at "education for citizenship" (33.3\%) and "social-economic development" (36.7\%). It is worth highlighting that most of the projects supported by the SSEs involve "education" (total mean of 44.6\%) if the three scopes related to education - special education, education for citizenship and education for sustainability - are analysed as a whole. 
Table 7. Scope of activities of the projects per country

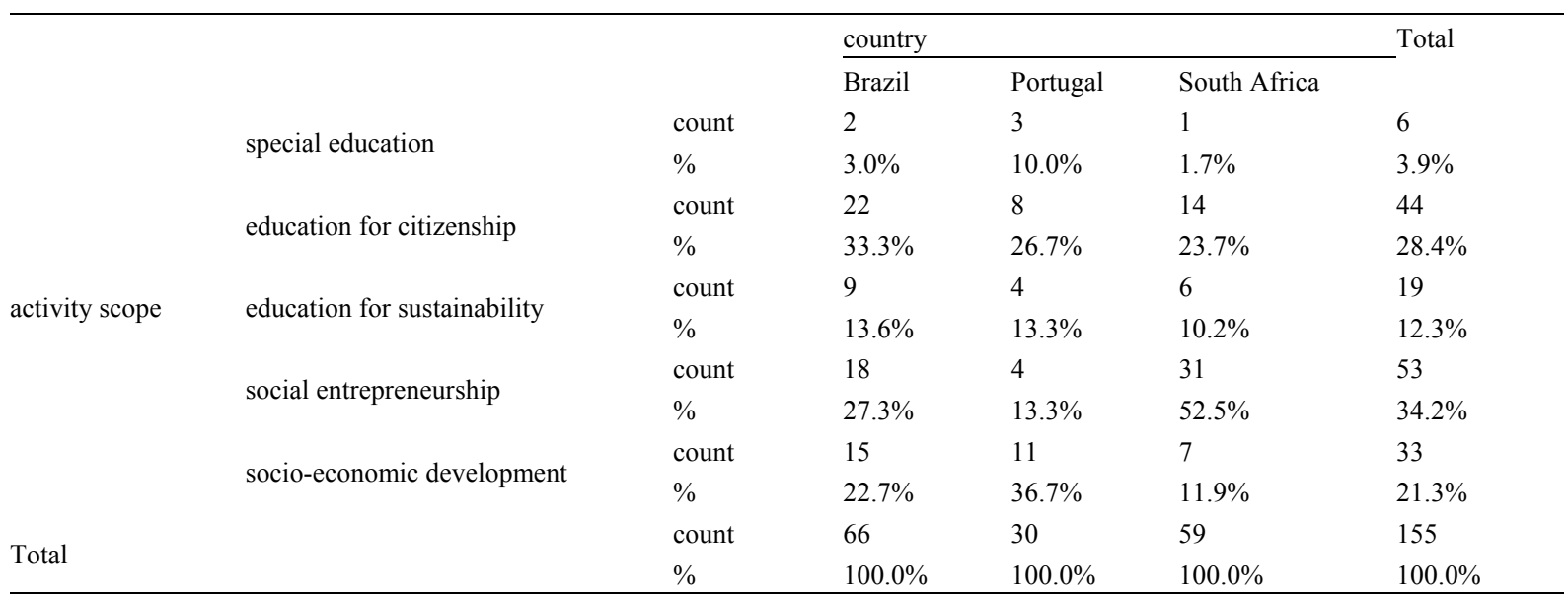

\subsubsection{Size of the Project}

Size of the project was also taken into account for analysis, and for this reason their values were converted into Euros. Table 8 lists the results, showing that most of the projects are large-sized ones (29.7\%), that is, with budgeted values ranging from 50,000 to 100,000 Euros. This situation is corroborated by Brazil, with $42.4 \%$ of large-sized projects, and Portugal, with $36.7 \%$ of x-large-sized and $33.3 \%$ of large-sized projects. On the other hand, in South Africa the SASIX projects are mostly micro-sized ones (47.5\%), that is, with maximum value of 10, 000 Euros.

Table 8 . Size of the projects per country

\begin{tabular}{|c|c|c|c|c|c|c|}
\hline & & & \multicolumn{3}{|l|}{ country } & \multirow[t]{2}{*}{ Total } \\
\hline & & & Brazil & Portugal & South Africa & \\
\hline \multirow{10}{*}{ size } & \multirow{2}{*}{ micro } & count & 11 & 1 & 28 & 40 \\
\hline & & $\%$ & $16.7 \%$ & $3.3 \%$ & $47.5 \%$ & $25.8 \%$ \\
\hline & \multirow{2}{*}{ small } & count & 9 & 5 & 16 & 30 \\
\hline & & $\%$ & $13.6 \%$ & $16.7 \%$ & $27.1 \%$ & $19.4 \%$ \\
\hline & \multirow{2}{*}{ medium } & count & 18 & 3 & 3 & 24 \\
\hline & & $\%$ & $27.3 \%$ & $10.0 \%$ & $5.1 \%$ & $15.5 \%$ \\
\hline & \multirow{2}{*}{ large } & count & 28 & 10 & 8 & 46 \\
\hline & & $\%$ & $42.4 \%$ & $33.3 \%$ & $13.6 \%$ & $29.7 \%$ \\
\hline & \multirow{2}{*}{$\mathrm{x}$-large } & count & 0 & 11 & 4 & 15 \\
\hline & & $\%$ & $0.0 \%$ & $36.7 \%$ & $6.8 \%$ & $9.7 \%$ \\
\hline \multirow{2}{*}{ Total } & & count & 66 & 30 & 59 & 155 \\
\hline & & $\%$ & $100.0 \%$ & $100.0 \%$ & $100.0 \%$ & $100.0 \%$ \\
\hline
\end{tabular}

\subsubsection{Three Dimensions of Sustainability (MDGs + ECO)}

The millennium goals proposed by the UN's Global Compact are divided into eight dimensions, whose objective is to ensure the sustainability of the planet, thus not incorporating economic aspects. For classification of the projects according to TBL guidelines (economic, social, and environmental), we believe that social and environmental aspects are covered by the eight objectives, but the economic aspect do not appear in any of the dimensions, then we evaluated whether the projects has economic purposes by using an independent variable. As listed in Table 9, it is possible to note that the projects are mainly aimed at education (26.5\%), and therefore they could contribute to achieving a universal primary education. Next, there are other three aspects that are uniformly distributed, namely: no related-MDG projects $(17.4 \%)$, poverty eradication $(16.1 \%)$, and environmental sustainability (16.1\%). In 2012, the Brazilian social stock exchange began presenting MDG-related projects, but we had to indentify MDGs in the earlier projects and in those from other countries that could be met by implementing the respective projects. When the projects are evaluated per country, it is possible to observed that in Brazil $34.8 \%$ of the projects are aimed at education, followed by $19.7 \%$ projects 
aimed at poverty eradication. Although these are third sector projects, one can observe that the government plans are aligned with this demand. In fact, Brazil has taken several actions to meet these goals. In the past decade, 28 million Brazilians had left the absolute poverty and 36 millions entered the middle class. However, even with this effort, 16 millions still are in extreme poverty.

In Portugal, $43 \%$ of the projects were not aligned with the MDGs, whereas the remaining ones were concerned with education (16.7\%) and poverty eradication (13.3\%). Like Brazil and Portugal, most of the South African projects were also aimed at education $(22 \%)$, but $18.6 \%$ were concerned with fighting HIV and other diseases, thus depicting the country's reality.

Table 9. Millennium development goals

\begin{tabular}{|c|c|c|c|c|c|c|}
\hline & & & country & & & Total \\
\hline & & & Brazil & Portugal & South Africa & \\
\hline & & count & 5 & 13 & 9 & 27 \\
\hline & Williout & $\%$ & $7.6 \%$ & $43.3 \%$ & $15.3 \%$ & $17.4 \%$ \\
\hline & & count & 13 & 4 & 8 & 25 \\
\hline & & $\%$ & $19.7 \%$ & $13.3 \%$ & $13.6 \%$ & $16.1 \%$ \\
\hline & To achieve univercal primary education & count & 23 & 5 & 13 & 41 \\
\hline & 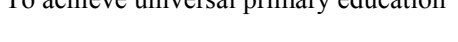 & $\%$ & $34.8 \%$ & $16.7 \%$ & $22.0 \%$ & $26.5 \%$ \\
\hline & To promete onder equolity & count & 1 & 2 & 2 & 5 \\
\hline & 10 piomote gentuer equanty & $\%$ & $1.5 \%$ & $6.7 \%$ & $3.4 \%$ & $3.2 \%$ \\
\hline millennium & To reduce child mortality & count & 4 & 0 & 5 & 9 \\
\hline development goals & 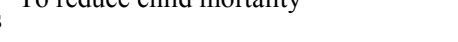 & $\%$ & $6.1 \%$ & $0.0 \%$ & $8.5 \%$ & $5.8 \%$ \\
\hline & To improve maternal health & count & 2 & 1 & 0 & 3 \\
\hline & ro improve maternal neain & $\%$ & $3.0 \%$ & $3.3 \%$ & $0.0 \%$ & $1.9 \%$ \\
\hline & To combat HIV and otherc & count & 2 & 1 & 11 & 14 \\
\hline & lo comoal niv allu otiers & $\%$ & $3.0 \%$ & $3.3 \%$ & $18.6 \%$ & $9.0 \%$ \\
\hline & To encure nuironmental suctainghility & count & 12 & 3 & 10 & 25 \\
\hline & to ensure environmental sustainability & $\%$ & $18.2 \%$ & $10.0 \%$ & $16.9 \%$ & $16.1 \%$ \\
\hline & To develon olohal nartnershin & count & 4 & 1 & 1 & 6 \\
\hline & 10 deverop giouar partiersmp & $\%$ & $6.1 \%$ & $3.3 \%$ & $1.7 \%$ & $3.9 \%$ \\
\hline & & count & 66 & 30 & 59 & 155 \\
\hline & & $\%$ & $100.0 \%$ & $100.0 \%$ & $100.0 \%$ & $100.0 \%$ \\
\hline
\end{tabular}

From the economic perspective, one can observe in Table 10 that $72.3 \%$ of the projects had no economic purpose in the three countries, that is, $72.7 \%$ and $81.4 \%$ of the projects being conducted in Brazil and South Africa, respectively. In Portugal, on the other hand, $46.7 \%$ of the projects were aimed at economic purposes. In other words, the Portuguese projects were more concerned with income generation and professional qualification for a given occupation.

Table 10. Economic goal

\begin{tabular}{|c|c|c|c|c|c|c|}
\hline & & & \multicolumn{3}{|l|}{ country } & \multirow[t]{2}{*}{ Total } \\
\hline & & & $\underline{\text { Brazil }}$ & Portugal & South Africa & \\
\hline \multirow{4}{*}{ economic goal } & \multirow{2}{*}{ non-economic goal } & count & 48 & 16 & 48 & 112 \\
\hline & & $\%$ & $72.7 \%$ & $53.3 \%$ & $81.4 \%$ & $72.3 \%$ \\
\hline & \multirow{2}{*}{ with economic goal } & count & 18 & 14 & 11 & 43 \\
\hline & & $\%$ & $27.3 \%$ & $46.7 \%$ & $18.6 \%$ & $27.7 \%$ \\
\hline \multirow{2}{*}{ Total } & & count & 66 & 30 & 59 & 155 \\
\hline & & $\%$ & $100.0 \%$ & $100.0 \%$ & $100.0 \%$ & $100.0 \%$ \\
\hline
\end{tabular}

\subsection{Discussion: Assessment of Attractiveness}

A quantitative assessment of the data obtained was performed in order to identify the most significant factors for the attractiveness of SSE projects. The categorical variables (public target, scope of activities, and MDGs) were converted into binary format so that the model of linear regression could be used, and the other variables were 
used as shown in Table 2

To avoid the effect of multicolinearity, variables that presented many categories of values were removed, in this case public target and MDG. The results of non-significance of the other variables remained.

In the next step, we have used linear regression with the remaining variables (Table 11). From these tests, it was observed a low adjusted $\mathrm{R}^{2}(0.2697)$ and a high p-test for the variables, which do not discriminate between successful and unaccomplished groups. Low p-test was found only in Portugal, showing that the Portuguese projects are different from those of South Africa in terms of size, whereas the Brazilian projects were not found to be significantly different from any of the other two countries. Therefore, the research model (equation 1) was not accepted, thus requiring a descriptive qualitative assessment to be made.

Table 11. Results of the regression analysis

\begin{tabular}{lllllll}
\hline Attractiveness & Coef. & Std. Err & $\mathbf{t}$ & $\mathbf{P}>|\mathbf{t}|$ & {$[\mathbf{9 5 \%}$ Con } & f. Interval] \\
\hline location & 0.01955 & 0.06076 & 0.32000 & 0.74800 & -0.10056 & 0.14 \\
geographic & -0.04234 & 0.08166 & -0.52000 & 0.60500 & -0.20375 & 0.12 \\
size_micro & 0.12068 & 0.12603 & 0.96000 & 0.34000 & -0.12843 & 0.37 \\
size_small & 0.04631 & 0.12627 & 0.37000 & 0.71400 & -0.20328 & 0.30 \\
size_medium & 0.18292 & 0.13472 & 1.36000 & 0.17700 & -0.08337 & 0.45 \\
size_large & 0.19706 & 0.11856 & 1.66000 & 0.09900 & -0.03731 & 0.43 \\
country_Brazil & -0.00917 & 0.07410 & -0.12000 & 0.90200 & -0.15565 & 0.14 \\
country_Portugal & -0.55337 & 0.09643 & -5.74000 & - & -0.74398 & -0.36 \\
economic_goal & 0.06746 & 0.08745 & 0.77000 & 0.44200 & -0.10541 & 0.24 \\
active_education & -0.00015 & 0.10215 & - & 0.99900 & -0.20207 & 0.20 \\
active_socioecon & -0.00444 & 0.10235 & -0.04000 & 0.96500 & -0.20675 & 0.20 \\
constant & 0.65637 & 0.14062 & 4.67000 & - & 0.37840 & 0.93 \\
\hline
\end{tabular}

\subsubsection{Public Target}

The majority of the projects studied were aimed at assisting children, traditional populations, youth, and handicapped people (Table 12). However, indigenous (100\%), youth (78\%), women (75\%), blacks/Afro-descendents $(67 \%)$, and children $(67 \%)$ were the communities having more success in raising resources. Projects for elderly ( $0 \%)$ and handicapped (48.1\%) populations had less financial attractiveness.

Table 12. Public target by the projects

\begin{tabular}{|c|c|c|c|c|c|c|c|c|c|c|}
\hline & & & children & youth & Elderly & indigenous & traditional & women & disabilities & negroes \\
\hline \multirow{4}{*}{ Attractiveness } & \multirow{2}{*}{ unaccomplished } & count & 13 & 7 & 4 & 0 & 17 & 2 & 14 & 1 \\
\hline & & $\%$ & $32.5 \%$ & $21.9 \%$ & $100 \%$ & $0 \%$ & $44.7 \%$ & $25 \%$ & $51.9 \%$ & $33.3 \%$ \\
\hline & \multirow{2}{*}{ successful } & count & 27 & 25 & $0 \%$ & 3 & 21 & 6 & 13 & 2 \\
\hline & & $\%$ & $67.5 \%$ & $78.1 \%$ & $0 \%$ & $100 \%$ & $55.3 \%$ & $75 \%$ & $48.1 \%$ & $66.7 \%$ \\
\hline Total & & count & 40 & 32 & 4 & 3 & 38 & 8 & 27 & 3 \\
\hline
\end{tabular}

\subsubsection{Location}

Crosstab analysis in Table 13 shows that there is a slight superiority of those projects whose seats are located out of the capitals (67.5\%) compared to those located in the capitals (57.3\%) regarding the investment attractiveness. This may be related to the fact that communities in smaller cities tend to better mobilise by articulating themselves more easily to promote social projects and divulge results.

Table 13. Location of the projects

\begin{tabular}{lllll}
\hline & & & countryside & capital \\
\hline \multirow{3}{*}{ Attractiveness } & \multirow{2}{*}{ unaccomplished } & count & 26 & 32 \\
& & $\%$ & $32.5 \%$ & $42.7 \%$ \\
\multirow{2}{*}{ Total } & successful & count & 54 & 43 \\
\hline
\end{tabular}




\subsubsection{Geographic Scope}

As seen elsewhere, at least $84.5 \%$ of the social projects have a national reach, but Table 14 shows that both regional and national projects had a mean financial attractiveness of $63.4 \%$ and $58.3 \%$, respectively.

Table 14. Geographic scope of the projects

\begin{tabular}{lllll}
\hline & & & regional & national \\
\hline \multirow{3}{*}{ Attractiveness } & \multirow{2}{*}{ unaccomplished } & count & 48 & 10 \\
& & $\%$ & $36.6 \%$ & $41.7 \%$ \\
& \multirow{3}{*}{ Total } & count & 83 & 14 \\
& & $\%$ & $63.4 \%$ & $58.3 \%$ \\
\hline
\end{tabular}

\subsubsection{Scope of Activities}

By comparing attractiveness to scope of activity in Table 15, projects aimed at "education for citizenship" and "social entrepreneurship" were those presenting the highest rate of success for resource raising among the three SSE projects (respectively, 68.2\% and 67.9\%), followed by "social-economic development" (60.6\%). If one considers the success rate regarding the three educational classes, then one can find a mean of $49.6 \%$, which is lower than the rates presented in other non-educational categories.

Table 15. Activity scope of the projects

\begin{tabular}{|c|c|c|c|c|c|c|c|}
\hline & & & $\begin{array}{l}\text { Special } \\
\text { education }\end{array}$ & $\begin{array}{l}\text { Education for } \\
\text { citizenship }\end{array}$ & $\begin{array}{l}\text { Education for } \\
\text { sustainability }\end{array}$ & $\begin{array}{l}\text { Social } \\
\text { enterpreneurship }\end{array}$ & $\begin{array}{l}\text { Socio-economic } \\
\text { development }\end{array}$ \\
\hline \multirow{4}{*}{ Attractiveness } & unaccomplished & count & 4 & 14 & 10 & 17 & 13 \\
\hline & & $\%$ & $66.7 \%$ & $31.8 \%$ & $52.6 \%$ & $32.1 \%$ & $39.4 \%$ \\
\hline & successful & count & 2 & 30 & 9 & 36 & 20 \\
\hline & & $\%$ & $33.3 \%$ & $68.2 \%$ & $47.4 \%$ & $67.9 \%$ & $60.6 \%$ \\
\hline Total & & count & 6 & 44 & 19 & 53 & 33 \\
\hline
\end{tabular}

\subsubsection{Size of the Projects}

The size of the projects seems to have no influence on the success or failure in raising resources, as shown in Table 16, since the success rate is higher than the failure rate in almost all size ranges, except for $\mathrm{x}$-large sized projects $(20 \%)$. However, a relative analysis shows micro. Medium and large-sized projects are those being more successful in obtaining resources $(72.5 \%, 70.8 \%$ and $69.6 \%$, respectively).

Table 16. Size of the projects

\begin{tabular}{|c|c|c|c|c|c|c|c|}
\hline & & & micro & small & medium & large & $\mathrm{x}$-large \\
\hline \multirow{4}{*}{ Attractiveness } & \multirow{2}{*}{ unaccomplished } & count & 11 & 14 & 7 & 14 & 12 \\
\hline & & $\%$ & $27.5 \%$ & $46.7 \%$ & $29.2 \%$ & $30.4 \%$ & $80 \%$ \\
\hline & \multirow{2}{*}{ successful } & count & 29 & 16 & 17 & 32 & 3 \\
\hline & & $\%$ & $72.5 \%$ & $53.3 \%$ & $70.8 \%$ & $69.6 \%$ & $20 \%$ \\
\hline Total & & count & 40 & 30 & 24 & 46 & 15 \\
\hline
\end{tabular}

\subsubsection{The Three Dimensions of Sustainability}

It is possible to observe in Table 17 that out of the 155 projects, 41 are concerned with education, all presenting a high attractiveness rate (75.6\%). However, there are also other MDGs related to a successful resource raising, such as: improvement of maternal health (100\%), fight against HIV/AIDs and other diseases (78.6\%), and eradication of poverty $(68 \%)$. It is also important to emphasise that among the 27 projects with no MDG being identified, $63 \%$ had failed in obtaining resources. 
Table 17. MDG

\begin{tabular}{|c|c|c|c|c|c|c|c|c|c|c|c|}
\hline & & & $\begin{array}{l}\text { Without } \\
\text { MDG }\end{array}$ & $\begin{array}{l}\text { Eradicate } \\
\text { poverty }\end{array}$ & $\begin{array}{l}\text { Achieve } \\
\text { universal } \\
\text { primary } \\
\text { education }\end{array}$ & $\begin{array}{l}\text { Promote } \\
\text { gender } \\
\text { equality }\end{array}$ & $\begin{array}{l}\text { Reduce } \\
\text { child } \\
\text { mortality }\end{array}$ & $\begin{array}{l}\text { Improve } \\
\text { maternal } \\
\text { health }\end{array}$ & $\begin{array}{l}\text { Combat } \\
\text { HIV and } \\
\text { others }\end{array}$ & $\begin{array}{l}\text { Ensure } \\
\text { environmental } \\
\text { sustain. }\end{array}$ & $\begin{array}{l}\text { Global } \\
\text { partnership } \\
\text { for develop. }\end{array}$ \\
\hline \multirow{3}{*}{ Attractiveness } & \multirow{2}{*}{ Unaccomplished } & count & 17 & 8 & 10 & 2 & 4 & 0 & 3 & 11 & 3 \\
\hline & & $\%$ & $63 \%$ & $32 \%$ & $24.4 \%$ & $40 \%$ & $44.4 \%$ & $0 \%$ & $21.4 \%$ & $44 \%$ & $50 \%$ \\
\hline & successful & $\%$ & $37 \%$ & $68 \%$ & $75.6 \%$ & $60 \%$ & $55.6 \%$ & $100 \%$ & $78.6 \%$ & $56 \%$ & $50 \%$ \\
\hline Total & & count & 27 & 25 & 41 & 5 & 9 & 3 & 14 & 25 & 6 \\
\hline
\end{tabular}

The fact that social projects can have economic purposes was not of concern for investors, as can be seen in Table 16, since $65.2 \%$ of the non-profit projects had a high rate of attractiveness and $55.8 \%$ of those with economic purposes succeeded in raising resources. Analysis of Table 17 and Table 18 indicates that the most relevant value created by these projects is social, nevertheless some of them have also indirectly generated some economic value, particularly by means of jobs and services. These findings confirm the literature review showing that social entrepreneur may produce private gains in the process of creating social value (Emerson \& Twersky, 1996).

Table 18. Economic goal

\begin{tabular}{|c|c|c|c|c|}
\hline & & & Non-economic goal & With economic goal \\
\hline \multirow{4}{*}{ Attractiveness } & \multirow{2}{*}{ unaccomplished } & count & 39 & 19 \\
\hline & & $\%$ & $34.8 \%$ & $44.2 \%$ \\
\hline & \multirow{2}{*}{ successful } & count & 73 & 24 \\
\hline & & $\%$ & $65.2 \%$ & $55.8 \%$ \\
\hline Total & & count & 112 & 43 \\
\hline
\end{tabular}

\subsection{Project Attractiveness Pattern}

In order to identify a project attractiveness pattern in the social stock exchanges, one of the objectives of the present article, the results of qualitative analysis were used to list the most representative categories for each variable in question, either positively (higher rate of attractiveness) or negatively (lower rates of attractiveness). Table 19 shows these categories and their respective attractiveness rates.

Table 19. Attractiveness per category

\begin{tabular}{lll}
\hline Attractiveness Variables & Successful level $(*)$ & Unaccomplished level \\
\hline Public target & indigenous $(100.0 \%)$ & elderly $(100 \%)$ \\
& youth $(78.1 \%)$ & \\
& women $(75.0 \%)$ & -- \\
Location & --- & x-large $(80 \%)$ \\
Size & Micro $(72.5 \%)$ & \\
& Medium $(70.8 \%)$ & Special education $(66.7 \%)$ \\
Scope of activity & ---- & -- \\
Geographic scope & --- & -- \\
MDG & To improve maternal health $(100 \%)$ & \\
& To combat HIV and others $(78.6 \%)$ & \\
& To achieve universal primary education & \\
economic goal & $(75.6 \%)$ & -- \\
\hline
\end{tabular}

(*) Successful Level includes projects with attractiveness up to $70 \%$.

For establishing a project attractiveness pattern, we have considered the variables having a participation of at least $70 \%$ in the attractiveness rates. As a result, the variables being less relevant in terms of financial 
attractiveness were the following: location (despite the predominance of projects located in the countryside); activity (despite "education for citizenship and "social entrepreneurship" almost reached 70\%), geographic scope, and economic sustainability.

In this way, we have proposed a project attractiveness pattern in which other variables evaluated were also taken into consideration, including their most relevant categories in terms of investment attractiveness, namely: size (micro and medium), public target (indigenous, youth, women), and MDGs (maternal health, fight against HIV/AIDs and other diseases, education). Therefore, one can state that these project categories are more likely to attract investments.

\section{Concluding Remarks}

This article has consolidated the theoretical approach to the topics of social entrepreneurship. According to the classification presented in the literature review (Costa \& Carvalho, 2012), the social organizations studied (SSE) refers to the initiatives of social organisations seeking alternative financing strategies or a way of creating social value through management practices (Austin et al., 2006; Boschee, 1998; Dees, 1998). It may contribute to the research on social entrepreneurship, since it is one of the areas needing investigation.

The main goal of this paper was to identify an attractiveness pattern of social project, then we examined the characteristics of all projects through linear regression. We expected to measure to what extent the variable "level of attractiveness" is dependent of other variables - public target, location, geographic scope, scope of activities, size, and three dimensions of sustainability: social, environmental (both measured through millennium development goals) and economic. The results showed that there is no linear relationship between attractiveness and the independent variables selected for this work. However it is not possible to conclude that a higher involvement of stakeholders and sponsors is not directly oriented towards the project characteristics considered in this paper (independent variables), because this relation (if existent) may be non-linear.

Future researches are needed to reach this statement because of limitations of our data base. One of these limitations refers to quantity of projects at SSEs, that despite of being in a proper number for the purpose of this paper, is not enough for using other regression techniques that allow us to identify non-linear relations (ex. regression multinomial logistic, regression binary logistic, probit and others). Another limitation is related to kind of data available for comparison at the three used databases, what precluded measurement of some factors or project characteristics which would be valuable metrics for social projects. For example, the link between reputable organisations having a wide contact network and history of success, history and organisational seniority, and entrepreneur pro-activity and stakeholders participation are important issues for the project attractiveness and consequently they should be better understood. Certo and Miller (2008) and Mair and Marti (2006) reported that difficulty on measuring social value.

Metrics to quantify the value created by each project could also be considered by sponsors or donators, so the existence of this type of metrics could improve the performance of the organisation. SSEs from Brazil and Portugal do not have metrics to quantify the value created, but the South African does as SASIX uses indicators similar to those used in the traditional stock exchanges.

The first specific objective was to describe the characteristics of SSE projects of three countries according to their respective differences and similarities. Possibly, differences (funding levels, public target, size and MDG) are due to distinct economic development level of the three studied countries, the needs met by government and others that are forgotten to society act (like the projects of SSE), value of parity of the currency to the euro, and the social entrepreneurship as defined by Peredo and McLean (2006) and Shaw and Carter (2007). Similarities (location, geographic scope, scope of activities) may be related to the core purpose of social business. Majority of projects focusing on regional scope in the three countries corroborates the fact that social innovations are created in locally embedded contexts (Shaw \& Carter, 2007). Unerman and O'Dwyer (2010) also conclude that NGO address different levels. Besides, social entrepreneurship and education for citizenship were the main scope of activities treated by analyzed projects, in a clear attempt to engendering systems for enabling people to help themselves, an intrinsic value added to social entrepreneurship, as pointed by Hockerts (2006).The second specific objective was to compare the characteristics to the financial attractiveness of the project in order to identify factors that were present in highly attractive projects. In spite of no confirmation of a linear relation among variables in our model for attractiveness, it was possible to identify some common vectors concerning the projects with success in funding. The pattern proposed in this paper indicates that attractiveness is more likely for micro and medium-sized projects (size) concerned with indigenous, youth and women (public target) and whose social and environmental sustainability are related to the following MDGs: maternal health, fight against HIV/AIDS and other diseases, and education. 
Finally, this study has presented a diversity of projects that demonstrate a strong creativity of social entrepreneurs, particularly in the fields of social cohesion and regional development, revealing that social entrepreneurship and its key players can definitely make a strong contribution to improving the welfare of populations. This work contributes to the study of social innovation (Phills et al., 2008) when we chose the SSEs as the objects of study. They incorporated the logic model from private initiative and the social results obtained from these projects could be embedded by society as proposed by Phills et al. (2008).

\section{Acknowledgements}

We thank the librarian staff of University of São Paulo for the support on bibliographic revision.

\section{References}

Aldrich, H., \& Zimmer, C. (1986). Entrepreneurship through social networks. In D. Sexton \& R. Smilor (Eds.), The art and science of entrepreneurship (pp. 3-23). New York, NY: Ballinger.

Alvord, S. H., Brown, L. D., \& Letts, C. W. (2002). Social entrepreneurship and social transformation: An exploratory study (Hauser Center for Nonprofit Organizations working paper No 15). Cambridge, MA: Harvard University.

Alvord, S. H., Brown, L. D., \& Letts, C. W. (2004). Social entrepreneurship and societal transformation. Journal of Applied Behavioral Science, 40, 260-282. http://dx.org.doi/10.1177/0021886304266847

Austin, J., Stevenson, H., \& Wei-Skillern, J. (2006). Social and commercial entrepreneurship: Same, different, or both? Entrepreneurship Theory and Practice, 30, 1-22. http://dx.org.doi/10.1111/j.1540-6520.2006.00107.x

Birley, S. (1985). The role of networks in the entrepreneurial process. Journal of Business Venturing, 1, 107-117.

Bolsa de Valores Sociais. (2012). Retrieved from http://www.bvs.org.pt/view/viewPrincipal.php

Bolsa de Valores Socioambientais. (2012). A BVSA. Retrieved from http://icepoverty.pbworks.com/f/bovespa_cs.pdf

Borzaga, C., \& Santuari, A. (2003). New trends in the non-profit sector in Europe: The emergence of social entrepreneurship. In Organisation for Economic Co-operation and Development, The non-profit sector in a changing economy (pp. 31-59). Paris, France: OCED.

Boschee, J. (1998). Merging mission and money: A board member's guide to social entrepreneurship. Retrieved from http://www.socialent.org/pdfs/MergingMission.pdf

Calás, M. B., Smircich, L., \& Bourne, K. A. (2009). Extending the boundaries: Reframing 'entrepreneurship as social change' through feminist perspectives. Academy of Management Review, 34, 552-569. http://dx.org.doi/10.5465/AMR.2009.40633597

Certo, S. T, \& Miller, T. (2008). Social entrepreneurship: Key issues and concepts. Business Horizons, 51, 267-271. http://dx.doi.org/10.1016/j.bushor.2008.02.009

Costa, T., \& Carvalho, L. (2012). Portuguese social stock exchange - assessment of sustainability. In C. Vivas \& F. Lucas (Eds.), Proceedings of the 7th European Conference on Entrepreneurship and Innovation (pp. 105-106). Sonning Common, England: Academic Publishing International.

Cruz, C. M. (2000). Captação de diferentes recursos para organizações sem fins lucrativos. São Paulo, SP: Global.

Dees, J. G. (1998). Enterprising nonprofits. Harvard Business Review, 76, 55-66.

Dees, J. G. (2001). The meaning of 'social entrepreneurship'. Retrieved from http://www.fuqua.duke.edu/centers/case/documents/dees_SE.pdf

Dees, J. G. (2007). Taking social entrepreneurship seriously. Society, 44(3), 24-31.

Domenico, L., Haugh, H., \& Tracey, P. (2010). Social bricolage: Theorizing social value creation in social enterprises. Entrepreneurship Theory and Practice, 33, 681-703. http://dx.org.doi/10.1111/j.1540-6520.2010.00370.x

Dorado, S. (2006). Social entrepreneurial ventures: Different values so different processes of creation, no? Journal of Developmental Entrepreneurship, 11, 319-343. http://dx.org.doi/10.1142/S1084946706000453

Emerson, J., \& Twersky, F. (Eds.). (1996). New social entrepreneurs: The success, challenge and lessons of non-profit enterprise creation. San Francisco, CA: Roberts Foundation/Homeless Economic Development Fund. 
Haugh, H. (2005). A research agenda for social entrepreneurship. Social Enterprise Journal, 1, 1-12. http://dx.org.doi/10.1108/17508610580000703

Hockerts, K. (2006). Entrepreneurial opportunity in social purpose ventures. In J. Mair, J. Robinson, \& K. Hockerts (Eds.), Social entrepreneurship (pp. 142-154). London, England: Palgrave Macmillan.

Johannisson, B. (2000). Networking and entrepreneurial growth. In D. Sexton \& H. Landstrom (Eds.), Handbook of entrepreneurship (pp. 368-386). London, England: Blackwell.

Leadbeater, C. (2007). Social enterprise and social innovation: Strategies for the next ten years. Cabinet Office of the Third Sector. from http://www.charlesleadbeater.net/cms/xstandard/social_enterprise_innovation.pdf

Light, P. C. (2006). Reshaping social entrepreneurship. Stanford Social Innovation Review, 4(3), 47-51.

Light, P. C. (2008). The search for social entrepreneurship. Washington, DC: Brookings Institution.

Mair, J. (2006). Introduction to part II: Exploring the intentions and opportunities behind social entrepre-neurship. In J. Mair, J. Robinson, \& K. Hockerts (Eds.), Social entrepreneurship (pp. 89-94). New York, NY: Palgrave Macmillan.

Mair, J., \& Marti, I. (2006). Social entrepreneurship research: A source of explanation, prediction, and delight. Journal of World Business, 41, 36-44. http://dx.doi.org/10.1016/j.jwb.2005.09.002

Mulgan, G., Tucker, S., Sli, R., \& Sanders, B. (2007). Social innovation-what it is, why it matters and how it can be accelerated. Oxford, England: The Young Foundation. Retrieved from http://www.sbs.ox.ac.uk/centres/skoll/research/Documents/Social\%20Innovation.pdf

Nancy, G., \& Yontcheva, B. (2006). Does NGO aid go to the poor? Empirical evidence from Europe (IMF Working paper, WP 06/39). Washington, DC: International Monetary Fund.

Neck, H., Brush, C., \& Allen, E. (2009). The landscape of social entrepreneurship. Business Horizons, 52, 3-19.

Peredo, A. M., \& McLean, M. (2006). Social entrepreneurship: A critical review of the concept. Journal of World Business, 41, 56-65. http://dx.doi.org/10.1016/j.jwb.2005.10.007

Phills, J. A., Jr., Deiglmeier, K., \& Miller, D. T. (2008). Rediscovering social innovation. Stanford Social Innovation Review, 6, 34-43.

Robinson, J. (2006). Navigating social and institutional barriers to markets: How social entrepreneurs identify and evaluate opportunities. In J. Mair, J. Robinson, \& K. Hockerts (Eds.), Social entrepreneurship (pp. 95-120). New York, NY: Palgrave Macmillan.

Sagawa, S., \& Segal, E. (2000). Common interest, common good: Creating value through business and social sector partnerships. Boston, MA: Harvard Business and Social Sector Partnership.

SASIX. (2012). All projects. Retrieved from http://www.sasix.co.za/projects/index/all

Seelos, C., \& Mair, J. (2005). Entrepreneurs in service of the poor-models for business contributions to sustainable development. Business Horizons, 48, 241-246.

Shaw, E., \& Carter, S. (2007). Social entrepreneurship: Theoretical antecedents and empirical analysis of entrepreneurial processes and outcomes. Journal of Small Business and Enterprise Development, 14, 418-434. http://dx.doi.org/10.1108/14626000710773529

Short, J. C., Moss, T. W., \& Lumpkin, G. T. (2009). Research in social entrepreneurship: Past contributions and future opportunities. Strategic Entrepreneurship Journal, 3, 161-194. http://dx.doi.org/10.1002/sej.69

Thompson, J. (2002). The world of the social entrepreneur. International Journal of Public Sector Management, 15, 412-431. http://dx.doi.org/10.1108/09513550210435746

Unerman, J., \& O'Dwyer, B. (2010). Ngo accountability and sustainability issues in the changing global environment. Public Management Review, 12, 475-486. http://dx.doi.org/10.1080/14719037.2010.496258

Venkataramann, S. (1997). The distinctive domain of entrepreneurship research: An editor's perspective. In J. Katz \& R. Brockhaus (Eds.), Advances in entrepreneurship firm emergence and growth (Vol. 3, pp. 119-138). Greenwich, CT: JAI Press.

Waddock, S. A. (1988). Building successful social partnerships. Sloan Management Review, 29(4), 17-22. 


\section{Copyrights}

Copyright for this article is retained by the author(s), with first publication rights granted to the journal.

This is an open-access article distributed under the terms and conditions of the Creative Commons Attribution license (http://creativecommons.org/licenses/by/3.0/). 